\title{
Purification and characterization of methyl-accepting chemotaxis protein methyltransferase I in Bacillus subtilis
}

\author{
Abul H. Jaffor ULLAH and George W. ORDAL \\ School of Basic Medical Sciences and Department of Biochemistry, 190 Medical Sciences Building, \\ University of Illinois, 506 South Mathews Avenue, Urbana, IL 61801, U.S.A.
}

(Received 31 July 1981/Accepted 19 August 1981)

\begin{abstract}
A methyltransferase that methylates one of the proteins involved in chemotactic adaptation to sensory stimuli in Bacillus subtilis was purified to homogeneity. The enzyme utilizes $S$-adenosylmethionine as donor for a methyl group that is transferred to a glutamate residue in a 69000-mol.wt. membrane protein and also to a protein of 19000 mol.wt. The molecular weights of the denatured enzyme by sodium dodecyl sulphate/polyacrylamide-gel electrophoresis and of the native enzyme by gel-filtration chromatography both show the protein to be a 44000 -mol.wt. monomer. Isoelectric focusing of the purified methyltransferase showed the protein to be a single species with isoelectric point pI 5.4. On the basis of a molecular weight of 44000 , the molar absorption coefficient at $262 \mathrm{~nm}$ of the enzyme is $10.9 \times 10^{4} \mathrm{M}^{-1} \cdot \mathrm{cm}^{-1}$. The $K_{\mathrm{m}}$ of the enzyme for $S$-adenosylmethionine is about $2 \mu \mathrm{M}$. The $K_{1}$ for $S$-adenosylhomocysteine is about $0.2 \mu \mathrm{M} . \mathrm{Ca}^{2+}$ is a competitive inhibitor of methylation, with a $K_{1}$ of $0.065 \mu \mathrm{M}$. The enzyme methylates membranes from the wild-type more efficiently than membranes isolated from a mutant strain defective in chemotaxis. The enzyme is unable to methylate Escherichia coli membranes.
\end{abstract}

Bacteria have developed a sophisticated sensory system that enables them to swim toward higher concentrations of attractants or lower concentrations of repellents. The swimming pattern is biased, because bacteria swim for longer periods when headed in a favourable direction (such as towards higher attractant concentrations) and for shorter periods when headed in an unfavourable direction, relative to duration of swims in isotropic medium (Berg \& Brown, 1972; Macnab \& Koshland, 1972). Swims are interrupted by tumbles, which serve to randomize direction of the next swim (Berg \& Brown, 1972).

One of the main features of the biochemical mechanism that dictates the tactic response to stimuli is a group of closely related intrinsic membrane proteins, collectively called 'methylaccepting chemotaxis proteins', which become methylated on addition of attractant to a suspension of bacteria (Kort et al., 1975; Springer et al., 1977; Silverman \& Simon, 1977). These methylations are an obligatory part of the bacterial chemosensing process, and appear to regulate adaptation to stimuli (Goy et al., 1977). The methyl group is present as a glutamate methyl ester in the methyl-accepting chemotaxis protein in Escherichia coli (Kleene et al., 1977) and Salmonella typhimurium (Van Der Werf

Abbreviation used: SDS, sodium dodecyl sulphate.
\& Koshland, 1977). In S. typhimurium the Che $R$ gene product is involved in the expression of a methyltransferase that catalyses the transfer of methyl groups from $S$-adenosylmethionine to the methyl-accepting chemotaxis protein (Springer \& Koshland, 1977). Further, a 38000-mol.wt. enzyme has been identified that methylates methyl-accepting chemotaxis protein in the membrane of $S$. typhimurium (Springer \& Koshland, 1977; Panasenko \& Koshland, 1979). S-Adenosylmethionine :protein $O$-methyltransferase has been purified in mammalian systems (Kim \& Paik, 1970; Galletti et al., 1978; Kim et al., 1980) and has been linked to leucocyte chemotaxis (O'Dea et al., 1978).

In order to expand our understanding of the biochemical mechanism that governs the sensory transduction mechanism of bacterial chemotaxis, we have investigated chemotactic methylation in vitro in Bacillus subtilis. The present paper reports the purification and characterization of an enzyme that methylates one of the methyl-accepting chemotaxis proteins of this bacterium.

\section{Materials and methods}

Strains

Wild-type strain of Bacillus subtilis was OI 1085. It was derived from strain OI 8 (Ordal \& Goldman, 
1975) as described by Ullah \& Ordal (1981). Strain OI 1085 is auxotrophic for histidine, tryptophan and methionine. Strains OI 1100 and OI 1141 were isolated as chemotaxis mutants from strain OI 1085 and were unable to show methylation of methylaccepting chemotaxis proteins in vivo in the absence of protein synthesis (Ullah \& Ordal, 1981). The wild-type strain of Escherichia coli was AW 405 (Hazelbauer et al., 1969).

\section{Chemicals}

$S$-Adenosyl $\left[\mathrm{Me}^{-3} \mathrm{H}_{3}\right]$ methionine was obtained from Amersham Corp. (Arlington Heights, IL, U.S.A.). Sepharose 2B and 4B were obtained from Pharmacia (Piscataway, NJ, U.S.A.). Bio-Gel P100, DEAE-Bio-Gel A and Affi-Gel Blue were obtained from Bio-Rad Laboratories (Richmond, CA, U.S.A.). Ampholines 5-7 were obtained from LKB Produkter (Stockholm, Sweden).

\section{Media}

Tryptone broth contained $1 \%$ tryptone and $0.5 \%$ $\mathrm{NaCl}$. L broth contained $1 \%$ tryptone, $0.5 \% \mathrm{NaCl}$ and $0.5 \%$ yeast extract. Sonication buffer was $10 \mathrm{~mm}$-potassium phosphate buffer, $\mathrm{pH} 7$, containing $10 \mathrm{~mm}-\mathrm{MgCl}_{2}, 1 \mathrm{~mm}$-EDTA, $0.3 \mathrm{~mm}$-dithiothreitol, $20 \mathrm{~mm}-\mathrm{KCl}, 2 \mathrm{~mm}$-phenylmethanesulphonyl fluoride and $20 \%(\mathrm{v} / \mathrm{v})$ glycerol. Methyltransferase buffer (MT buffer) was $10 \mathrm{~mm}$-potassium phosphate buffer, $\mathrm{pH} 7$, containing $1 \mathrm{mM}-\mathrm{MgCl}_{2}, 0.1 \mathrm{~mm}$-EDTA and $1 \mathrm{mM}$-2-mercaptoethanol.

\section{Growth conditions}

Spores (for B. subtilis) or early-stationary-phase cells frozen in $10 \%$ glycerol (for $E$. coli) were grown overnight to stationary phase in tryptone broth. Bacteria were transferred to 0.8-litre cultures in $\mathrm{L}$ broth and grown to $A_{600}$ of about 1.9 units.

\section{Preparation of crude soluble extract}

Bacteria were harvested by centrifugation in a JA-14 rotor at $10000 \mathrm{rev} . / \mathrm{min}(9900 \mathrm{~g})$ for 10 $15 \mathrm{~min}$ and washed three times with $1 \mathrm{M}-\mathrm{KCl}$ to remove possible proteinases (Nakayama et al., 1977). Cells were resuspended in sonication medium, which included phenylmethanesulphonyl fluoride to inactivate proteinases (Nakayama et al., 1977), subjected to sonic oscillation, and the debris was removed by centrifugation at $15000 \mathrm{rev} . / \mathrm{min}$ $(17600 \mathrm{~g})$ for $15 \mathrm{~min}$ in a JA-20 rotor. The supernatant was immediately passed through a haemoglobin-Sepharose 2B affinity column to remove possible residual proteinases (Nakayama et al., 1977), and the column eluate was treated with $10 \mu \mathrm{g}$ of deoxyribonuclease $/ \mathrm{ml}$ and $15 \mu \mathrm{g}$ of ribonuclease/ $\mathrm{ml}$ for $30 \mathrm{~min}$ at $37^{\circ} \mathrm{C}$. Membranes were removed by centrifugation at $40000 \mathrm{rev} . / \mathrm{min}(120000 \mathrm{~g})$ for $2 \mathrm{~h}$ in a Beckman $70 \mathrm{Ti}$ rotor, and the supernatant was dialysed for $24 \mathrm{~h}$ against four changes of MT buffer in a rapid dialyser to give the 'crude soluble extract' (see the Results section).

\section{Preparation of membrane for assay}

The pelleted membranes were resuspended in MT buffer, and homogenized in a glass/Teflon homogenizer and re-centrifuged. This step was repeated once more. Finally, the membranes were homogenized in MT buffer at a concentration of $32 \mathrm{mg} / \mathrm{ml}$ and stored at $-70^{\circ} \mathrm{C}$.

Assay

The procedure of Springer \& Koshland (1977) was followed, with modifications. A $24 \mu \mathrm{g}$ portion of membrane in $6 \mu \mathrm{l}$ of MT buffer, $14 \mu \mathrm{l}$ of methyltransferase (or buffer as control), $1 \mu \mathrm{l}$ of $25 \mathrm{~mm}$ sodium citrate $/ 25 \mathrm{~mm}$-sodium EGTA, $\mathrm{pH} 7$, were mixed and the reaction was begun by addition of $1 \mu \mathrm{Ci}(0.1 \mathrm{nmol})$ of $S$-adenosyl $\left[\mathrm{Me}^{-3} \mathrm{H}_{3}\right]$ methionine to make the total volume $25 \mu \mathrm{l}$. Assay tubes were incubated at $37^{\circ} \mathrm{C}$ for $15 \mathrm{~min}$, and the methylation reaction was terminated by addition of $5 \mathrm{ml}$ of cold $20 \mathrm{~mm}$-sodium acetate buffer, $\mathrm{pH} 4.0$. The diluted mixtures were filtered on Millipore filters and washed twice with $5 \mathrm{ml}$ of the sodium acetate buffer, and the filters were dried and counted for radioactivity in a scintillation spectrometer.

\section{Preparation of affinity columns}

The haemoglobin-Sepharose 2B affinity column was prepared as follows: Sepharose $2 \mathrm{~B}$ was activated with $\mathrm{CNBr}$ by the method of March et al. (1974) and bound covalently with haemoglobin (type II from Sigma Chemical Co., St. Louis, MO, U.S.A.) by the procedure of Chua \& Bushuk (1969).

For the preparation of $S$-adenosylhomocysteineSepharose 4B for affinity chromatography, the gel matrix bromoacetamidoethyl-Sepharose 4B was prepared by the method of Cuatrecasas (1970). $S$-Adenosylhomocysteine was added to the Sepharose 4B derivative in $0.1 \mathrm{M}-\mathrm{NaHCO}_{3}, \mathrm{pH} 8.5$, and swirled gently at $40^{\circ} \mathrm{C}$ for 3 days. Unmodified bromoacetyl groups were masked by subsequent reaction with $0.1 \mathrm{M}$-aminoethanol at $40^{\circ} \mathrm{C}$ for 2 days. The resulting $S$-adenosylhomocysteineSepharose 4B gel was extensively washed and equilibrated with MT buffer before use.

\section{Chromatography}

A haemoglobin-Sepharose 2B affinity column was used to remove possible residual proteinases from the sonicated extract after removal of cellular debris. The cellular fluid was passed through a $1.5 \mathrm{~cm} \times 12 \mathrm{~cm}$ column and washed with 1 column volume of sonication buffer. The column was regenerated by washing with $0.1 \mathrm{M}$-acetic acid and then with sonication buffer. 
A Bio-Gel P-100 (gel-filtration) column was used to assess the molecular weight of native methyltransferase. Proteins from the crude soluble extract (membrane removed) were precipitated with $95 \%$ saturated enzyme-grade $\left(\mathrm{NH}_{4}\right)_{2} \mathrm{SO}_{4}$, redissolved in a small volume, and applied to a $2.0 \mathrm{~cm} \times 60 \mathrm{~cm}$ column (100-200 mesh) pre-equilibrated with MT buffer. The column was developed at a flow rate of $0.3 \mathrm{ml} / \mathrm{min}$, and $2.5 \mathrm{ml}$ fractions were collected. Before the experiment, it had been calibrated with Blue Dextran (mol.wt. 2000000), fructose bisphosphate aldolase (mol.wt. 160000), ovalbumin (mol.wt. 45000), chymotrypsinogen A (mol.wt. 25000) and cytochrome $c$ (mol.wt. 12400).

A DEAE-Bio-Gel A column was used to fractionate the crude extract in purification of the methyltransferase. The dialysed crude soluble extract was applied to a $2.0 \mathrm{~cm} \times 12.5 \mathrm{~cm}$ column preequilibrated with MT buffer followed by a $250 \mathrm{ml}$ linear gradient of $0-0.3 \mathrm{M}-\mathrm{KCl}$ in MT buffer; $5 \mathrm{ml}$ fractions were collected.

A $S$-adenosylhomocysteine-Sepharose 4B affinity column was used for further purification of methyltransferase after the DEAE-Bio-Gel A column. Enzyme solution was applied to a $2.0 \mathrm{~cm} \times 6.0 \mathrm{~cm}$ column pre-equilibrated with MT buffer and washed with $100 \mathrm{ml}$ of MT buffer. Enzyme was eluted with a $100 \mathrm{ml}$ linear gradient of $0-0.15 \mathrm{M}-\mathrm{NaCl}$ in $\mathrm{MT}$ buffer; $5 \mathrm{ml}$ fractions were collected.

An Affi-Gel Blue column was used for final purification of methyltransferase. A $2.0 \mathrm{~cm} \times 5.0 \mathrm{~cm}$ column was pre-equilibrated with $\mathrm{MT}$ buffer, and eluate from the $S$-adenosylhomocysteine-Sepharose 4B affinity column was applied. The column was washed with several column volumes of MT buffer.

\section{Protein determination}

The procedure of Sedmak \& Grossberg (1977) was followed. In this method, a $0.06 \%$ solution of Coomassie Brilliant Blue G-250 was dissolved in 3\% $(\mathrm{w} / \mathrm{v}) \mathrm{HClO}_{4}$, and the solution was filtered to remove undissolved particles. Then $0.5 \mathrm{ml}$ of protein solution in $0.15 \mathrm{M}-\mathrm{NaCl}$ was added to $0.5 \mathrm{ml}$ of dye solution, and the absorbance at $620 \mathrm{~nm}$ was read. The blank value, obtained by adding only saline to the dye solution, was subtracted. Several concentrations of ovalbumin were analysed by this procedure in the same experiment. It was found that a graph of the reciprocal of protein concentration on the abscissa versus the reciprocal of $A_{620}$ on the ordinate gave a straight line, so that protein concentrations corresponding to $A_{620}$ for unknown samples were determined from a double-reciprocal plot made by using the values from the ovalbumin standards run on the same day.

\section{SDS/polyacrylamide-gel electrophoresis}

Electrophoresis in SDS/polyacrylamide gels (10\% monomer) were performed by the method of Laemmli (1970). Experiments were performed at $4^{\circ} \mathrm{C}$, and the slab gel was immediately stained with Coomassie Brilliant Blue R-250 and then destained in $10 \%(\mathrm{v} / \mathrm{v})$ acetic acid. For detection of the product of the methyltransferase reaction, a gradient of $10-18 \%$ in acrylamide monomer $(0.125-0.225 \%$ in bisacrylamide monomer) was used, followed by fluorography (Ullah \& Ordal, 1981).

\section{Isoelectric focusing}

Isoelectric focusing was performed in polyacrylamide gels at $40^{\circ} \mathrm{C}$ by a modification of the method of Catterall (1976). Tubular gels $(5 \mathrm{~mm} \times 100 \mathrm{~mm})$ were prepared by ammonium persulphate-catalysed polymerization of acrylamide ( $7.5 \%$ monomer). Gels contained $2.2 \%(\mathrm{v} / \mathrm{v})$ Ampholine 5-7. The sample $(75 \mu \mathrm{l})$ was made $10 \%(\mathrm{w} / \mathrm{v})$ in sucrose and $0.1 \%$ (v/v) in Ampholine 5-7. It was then loaded on top of the gel and overlaid with $100 \mu \mathrm{l}$ of $5 \%(\mathrm{w} / \mathrm{v})$ sucrose and $0.1 \%(\mathrm{v} / \mathrm{v})$ Ampholine 5-7. Tubes were then filled with cathode buffer $[0.4 \%(\mathrm{v} / \mathrm{v})$ ethanolamine] and immersed in anode buffer $\left[0.2 \%(\mathrm{v} / \mathrm{v}) \mathrm{H}_{2} \mathrm{SO}_{4}\right]$ in an electrophoresis chamber. An electric field of $50 \mathrm{~V}$ was applied for $0.5 \mathrm{~h}$ and then increased to $150 \mathrm{~V}$ for $6 \mathrm{~h}$. Proteins in the gels were fixed by immersion in cold $10 \%(w / v)$ trichloroacetic acid. Gels were then dialysed against $10 \%(\mathrm{w} / \mathrm{v})$ trichloroacetic acid (three changes) for $24 \mathrm{~h}$ to remove ampholytes and finally stained with Coomassie Brilliant Blue R-250 (Fairbanks et al., 1971).

\section{Proteolytic digestion of the methylated membrane proteins}

Wild-type membrane $(3.2 \mathrm{mg})$ was methylated by methyltransferase $(0.055 \mathrm{mg})$ for $1 \mathrm{~h}$ at $32^{\circ} \mathrm{C}$ in presence of $1 \mathrm{mM}$-EGTA, citrate and $12.5 \mu \mathrm{Ci}$ of $S$-adenosylmethionine in a total volume of $0.4 \mathrm{ml}$. The reaction was stopped by adding an equal volume of 2 -fold-concentrated Laemmli solubilizer (Laemmli, 1970). The product was fractionated by electrophoresis in $10 \%$ SDS/polyacrylamide gels. The 69000 -mol.wt. and 19000 mol.wt. regions were removed from the gel, macerated, and the proteins eluted in $10 \mathrm{ml}$ of $50 \mathrm{~mm}$ sodium acetate buffer, pH5.2, containing $1 \%$ Triton X-100. The gel was removed by centrifugation and the protein precipitated in $12.5 \%(\mathrm{w} / \mathrm{v})$ trichloroacetic acid. The precipitate was washed twice with $5 \%$ trichloroacetic acid, once with acetone $/ 1 \mathrm{M}-\mathrm{HCl}(1000: 1, \mathrm{v} / \mathrm{v})$, and finally twice with acetone. A modification of the procedure of Hill \& Schmidt (1962) for total enzymic digestion of protein was used. The precipitate was suspended in $3.5 \mathrm{ml}$ of $50 \mathrm{~mm}$-sodium acetate buffer, $\mathrm{pH} 5.2$, containing $0.2 \mathrm{~mm}$-EDTA and $5 \mathrm{mM}-2$-mercaptoethanol. Then 2 units of papain were added and 
the mixture was incubated at $37^{\circ} \mathrm{C}$ for $2 \mathrm{~h}$, adjusted to $\mathrm{pH} 2.0$ with $1 \mathrm{M}-\mathrm{HCl}$ and freeze-dried. The freezedried residue was supplemented with $30 \mu \mathrm{l}$ of $0.5 \mathrm{M}$-Tris $/ \mathrm{HCl}$ buffer, $\mathrm{pH} 8.0,0.48 \mathrm{ml}$ of $0.1 \mathrm{M}$ $\mathrm{MnCl}_{2}, 100 \mu \mathrm{g}$ of leucine aminopeptidase (6 units), $200 \mu \mathrm{g}$ of prolidase (38 units) and water to a final volume of $3 \mathrm{ml}$. The sample was incubated at $37^{\circ} \mathrm{C}$ for $4 \mathrm{~h}$, centrifuged, and the supernatant adjusted to $\mathrm{pH} 2$ with $1 \mathrm{M}-\mathrm{HCl}$. The solution was passed through a $0.45 \mu \mathrm{m}$ Millipore filter, freeze-dried and analysed by descending paper chromatography.

\section{Results}

\section{Identification of methyltransferase}

To study the methyltransferase, it was necessary to separate the enzyme from one of its natural substrates, the plasma membrane in which the methyl-accepting chemotaxis proteins are embedded. Such a separation would make it possible to quantify enzyme activity and determine strength of interaction between enzyme and the methyl-accepting chemotaxis proteins. We proceeded on the hypothesis that the methyltransferase is a soluble cytoplasmic enzyme and found, indeed, that the bulk of activity was in the supernatant and that much of the remainder could be washed off the membrane (by centrifugation and resuspension). The fact that incubation of increasing amounts of membrane (in the concentration range used in the assay with $S$-adenosylmethionine) in the absence of added methyltransferase gives rise to a linear increase of radioactivity (results not shown), rather than to a quadratic increase, indicates that the membranes were fairly uncontaminated with methyltransferase, although prolonged incubation did reveal some contamination (Fig. 10). Precipitation of this enzyme from the 'crude supernatant' (see the Materials and methods section) followed by chromatography on Bio-Gel P-100 (gel filtration) showed the enzyme to possess a single activity associated with protein of molecular weight about 44000 (Fig. 1), except for minor peaks of activity.

\section{Purification}

Bacteria were grown and treated as described in the Materials and methods section to produce a 'crude soluble supernatant' free of proteinase. This treatment included washing in $1 \mathrm{M}-\mathrm{KCl}$, sonication in the presence of phenylmethanesulphonyl fluoride, and passage through a haemoglobin-Sepharose 2B affinity column.

After extensive dialysis against MT buffer, the crude supernatant was loaded on a DEAE-Bio-Gel A column and washed extensively with buffer. The column was developed with a linear gradient of $0-0.3 \mathrm{M}-\mathrm{KCl}$ in buffer. The peak of activity was eluted at around $0.167 \mathrm{M}-\mathrm{KCl}$ (after the bulk of the

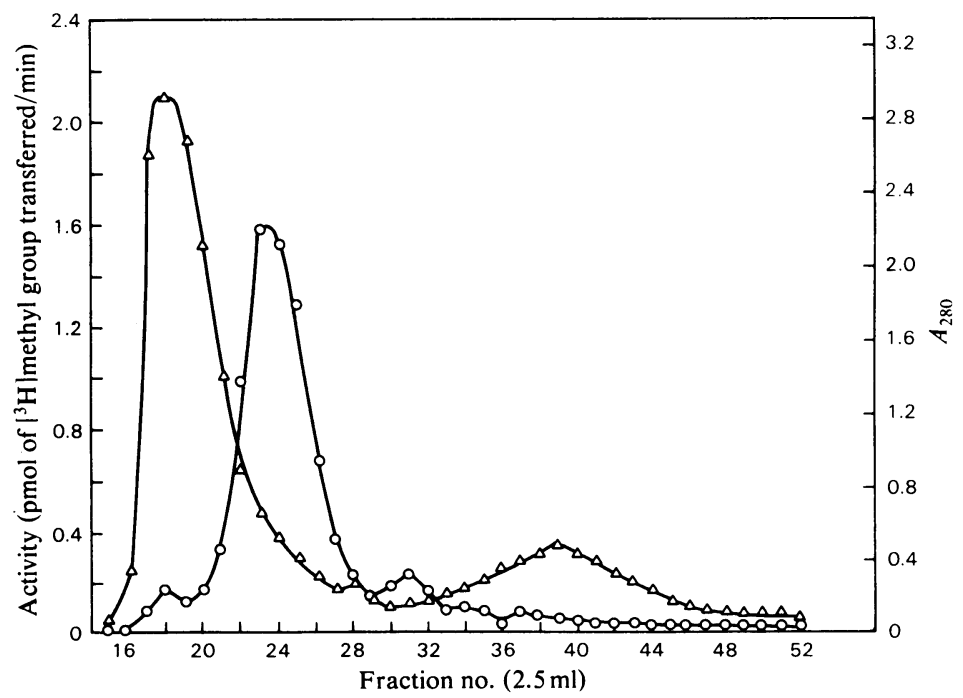

Fig. 1. Gel-filtration chromatography of dialysed crude extract on Bio-Gel P-100

The column was calibrated by using molecular-weight standards. Crude soluble extract ( $100 \mathrm{mg}$ of protein), previously concentrated by precipitation with $\left(\mathrm{NH}_{4}\right)_{2} \mathrm{SO}_{4}$ and dialysed, was applied to a column $(2.0 \mathrm{~cm} \times 60 \mathrm{~cm})$ of Bio-Gel P-100. The fractions were eluted and assayed as described in the Materials and methods section, except that the membrane concentration was $1.24 \mathrm{mg} / \mathrm{ml}$ and the incubation lasted $30 \mathrm{~min}$. $\mathrm{O}$, Methyltransferase activity; $\triangle, A_{280}$. 
protein had been eluted), as a slight shoulder (Fig. 2).

The active fractions from the DEAE-Bio-Gel A column were combined and extensively dialysed against MT buffer, and then applied to an $S$-adenosylhomocysteine-Sepharose 4B affinity column. The column was washed with $100 \mathrm{ml}$ of buffer, during which time the bulk of the protein was eluted, and then developed with a linear gradient of $0-0.15 \mathrm{M}-\mathrm{NaCl}$ in buffer. The bulk of the enzyme activity came off in the gradient at around $0.045 \mathrm{M}-\mathrm{NaCl}$ (Fig. 3). The earlier fractions were contaminated with other proteins, but the later fractions were increasingly pure.

Although most experiments could be done with

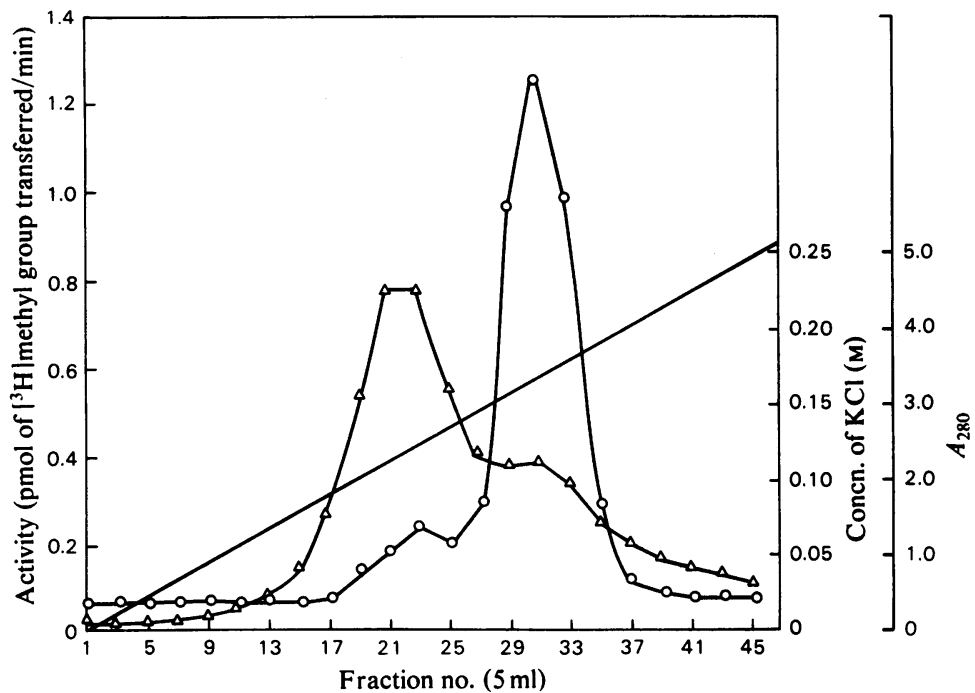

Fig. 2. Chromatography of dialysed crude extract on DEAE-Bio-Gel A

Crude soluble extract $(525 \mathrm{mg}$ of protein) was applied to a column $(2.0 \mathrm{~cm} \times 12.5 \mathrm{~cm})$ of DEAE-Bio-Gel A. The fractions were eluted and assayed as described in the Materials and methods section. 0 , Methyltransferase activity; $\triangle A_{280} ;-$, concentration of $\mathrm{KCl}$.

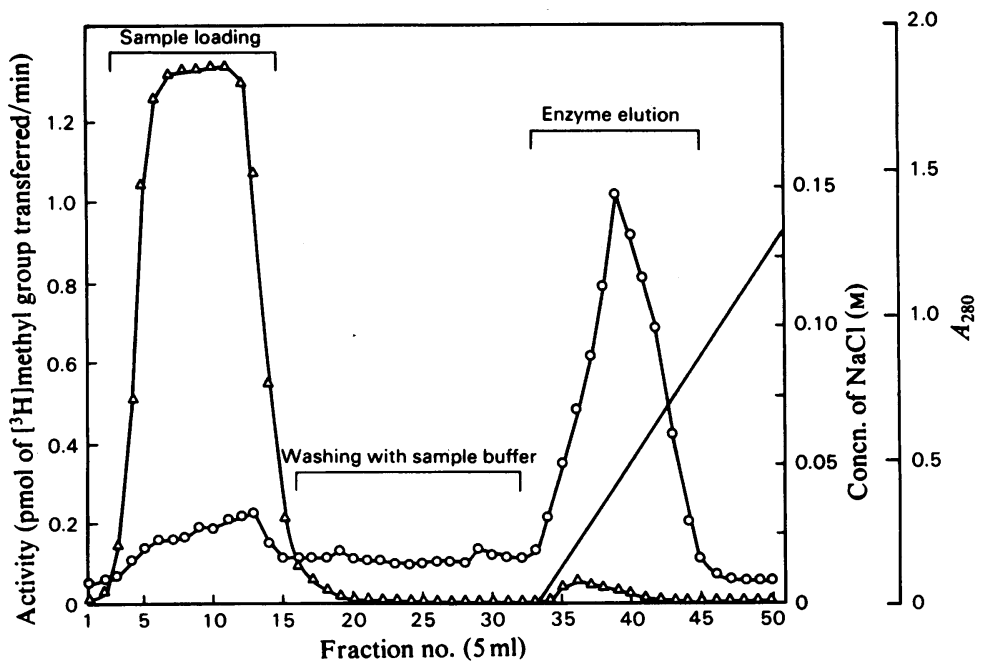

Fig. 3. Affinity chromatography of DEAE-Bio-Gel-A-purified methyltransferase on S-adenosylhomocysteineSepharose 4B

The partially purified enzyme solution ( $155 \mathrm{mg}$ of protein) was applied to a column $(2.0 \mathrm{~cm} \times 6.0 \mathrm{~cm})$ of $S$-adenosylhomocysteine-Sepharose 4B. The fractions were eluted and assayed as described in the Materials and methods section. O, Methyltransferase activity; $\triangle, A_{280} ;-$, concentration of $\mathrm{NaCl}$. 
the highly purified fractions from the $S$-adenosylhomocysteine-Sepharose 4B affinity column, the enzyme was further purified by passage through an Affi-Gel Blue column, which bound the contaminating proteins but not the methyltransferase.

The results obtained during a typical purification are shown in Table 1.

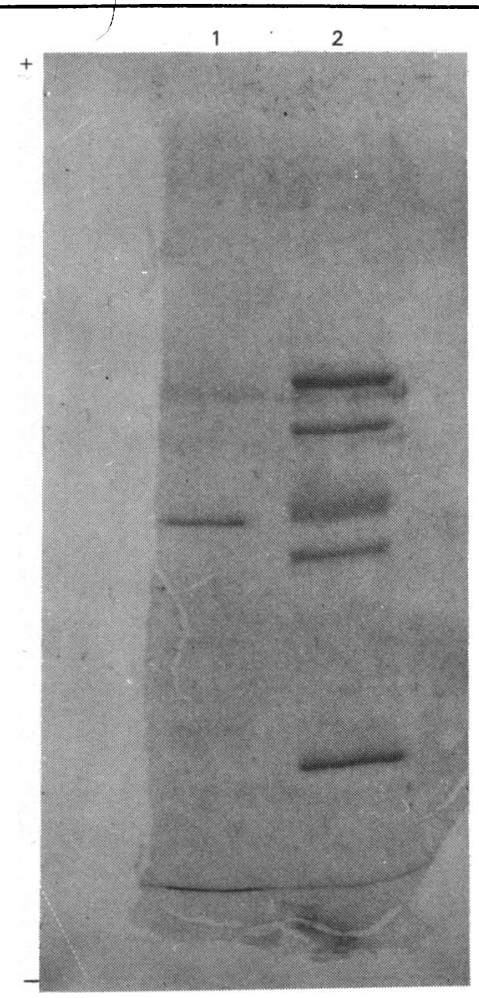

Fig. 4. SDS/polyacrylamide-gel electrophoresis of AffGel-Blue-purified methyltransferase

Electrophoresis was performed as described in the Materials and methods section. Lane 1, methyltransferase; lane 2, standards [bovine serum albumin (mol.wt. 67000); catalase (mol.wt. 60000); ovalbumin (mol.wt. 45000); fructose bisphosphate aldolase (mol.wt. 40000); chymotrypsinogen (mol.wt. 25 500)].

\section{Homogeneity and molecular weight}

The resulting enzyme was virtually pure, as analysed by SDS/polyacrylamide-gel electrophoresis (Fig. 4). Isoelectric focusing showed the protein to be a single species of isoelectric point 5.4 (Fig. 5).

On the basis of the known molecular weights of standards, the molecular weight of the denatured methyltransferase was found to be about 44000 . Gel filtration of the crude extract showed the molecular weight of the native enzyme to be about 44000 , on the basis of calibration of the column with known

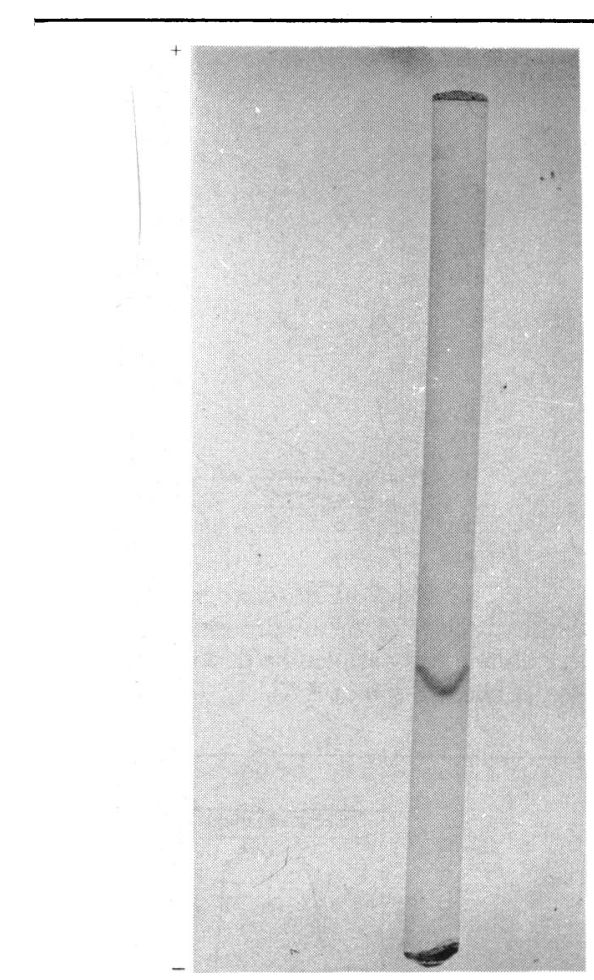

Fig. 5. Isoelectric focusing in polyacrylamide gel of Affi-Gel-Blue-purified methyltransferase

Electrophoresis was performed as described in the Materials and methods section.

Table 1. Purification of methyltransferase from $B$. subtilis

Experimental details are given in the text. The unit of activity is defined as the transfer of 1 pmol of $\left[{ }^{3} \mathrm{H}\right] \mathrm{methyl}$ group $/ \mathrm{min}$ at $37^{\circ} \mathrm{C}$.

Crude supernatant

\section{Purification step}

DEAE-Bio-Gel A chromatography

$S$-Adenosylhomocysteine-Sepharose affinity chromatography

Affi-Gel Blue chromatography

$\begin{array}{ccccc}\begin{array}{c}\text { Total } \\ \text { protein } \\ (\mathrm{mg})\end{array} & \begin{array}{c}\text { Specific } \\ \text { activity } \\ \text { (units/mg } \\ \text { of protein) }\end{array} & \begin{array}{c}\text { Total } \\ \text { activity } \\ \text { (units) }\end{array} & \begin{array}{c}\text { Purification } \\ \text { (fold) }\end{array} & \begin{array}{c}\text { Yield } \\ (\%)\end{array} \\ 527 & 0.18 & 95.1 & 1 & 100 \\ 157 & 0.44 & 68.5 & 2.44 & 72 \\ 0.737 & 55.6 & 41.0 & 309 & 43.1 \\ 0.435 & 76.4 & 33.2 & 424 & 34.9\end{array}$


standards. Therefore the enzyme appears to be a monomer in its active form.

\section{Spectral properties}

A u.v.-absorption spectrum of the enzyme was taken (Fig. 6). There was a maximum absorption at $262 \mathrm{~nm}$, with $A_{262} 2.494 / \mathrm{mg}$ of protein and $A_{280}$ $1.648 / \mathrm{mg}$ of protein. There was no appreciable absorption at higher wavelengths (results not shown).

\section{Kinetic study of the methyltransferase}

To determine whether methylation of substrate was linear with time, membrane from the wild-type was methylated with pure methyltransferase. The rate of incorporation was constant for $20 \mathrm{~min}$ (results not shown). Later experiments, with membranes prepared with the French press rather than the sonicated preparation, showed the rate to be constant for at least $60 \mathrm{~min}$ (results not shown).

To observe the effect of varying the amount of methyltransferase at constant membrane concentration, a range of concentrations from $0.04 \mu \mathrm{g}$ to $0.28 \mu \mathrm{g}$ of methyltransferase per reaction vial was tested. Methylation of membrane was directly proportional to amount of methyltransferase (results not shown).

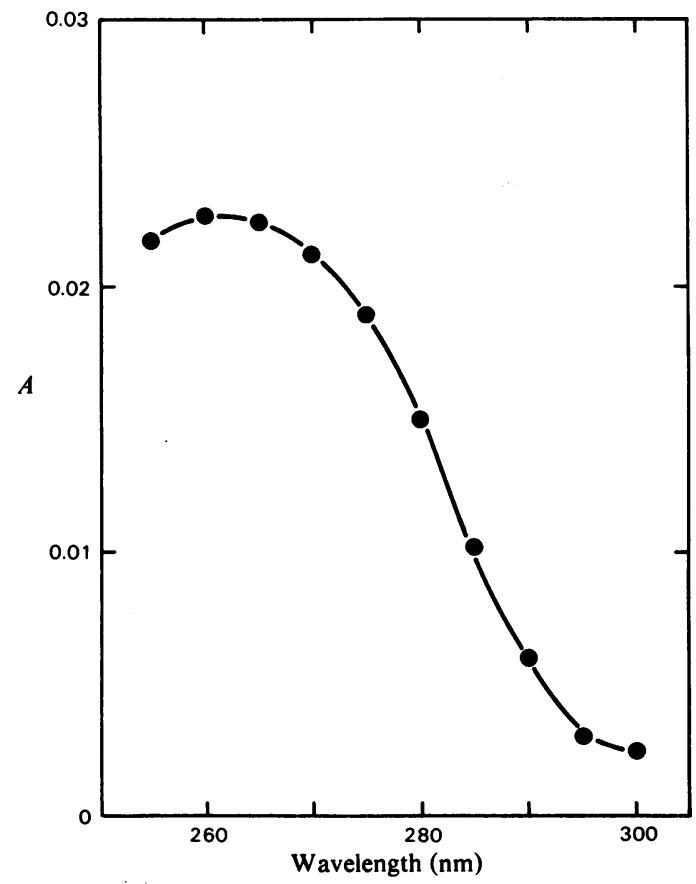

Fig. 6. U.v.-absorption spectrum of Affi-Gel-Bluepurified methyltransferase

An Aminco-Chance DW-2 spectrophotometer was used. The protein concentration was $8.64 \mu \mathrm{g} / \mathrm{ml}$. See the text for further details.
To observe the effect of varying the amount of membrane at constant methyltransferase concentration, different amounts of membrane from wildtype and mutant strains were methylated. Membrane from the wild-type showed markedly higher methylation than did membrane from the mutant at all concentrations tested (Fig. 7). Saturation of methylation occurred around 18-20 $\mu \mathrm{g}$ of membrane protein.

\section{Specificity}

To explore further the specificity of purified methyltransferase, membranes from $B$. subtilis wild-type and mutant strains OI 1100 and OI 1141, and from wild-type $E$. coli strain AW405, were subjected to conditions of methylation. The membranes from the mutants were methylated only $20-30 \%$ as well as those from $B$. subtilis wild-type, and $E$. coli membranes were not methylated at all (Table 2).

\section{Inhibition by $S$-adenosylhomocysteine}

$S$-Adenosylhomocysteine is a well-known product inhibitor for many $S$-adenosylmethioninedependent methyltransferases (Kim, 1974). To investigate the inhibition of the present methyltransferase by $S$-adenosylhomocysteine, the methyltransferase assay was performed in the presence and in the absence of $0.2 \mu \mathrm{M}-S$-adenosylhomocysteine, and the results were plotted by the Lineweaver-Burk method (Fig. 8). From these data, the $K_{\mathrm{m}}$ for $S$-adenosylmethionine was found to be $2 \mu \mathrm{M}$ and the $K_{1}$ for $S$-adenosylhomocysteine as competitive inhibitor was found to be $0.2 \mu \mathrm{M}$.

Inhibition by $\mathrm{Ca}^{2+}$

Because of implications that $\mathrm{Ca}^{2+}$ plays a role in

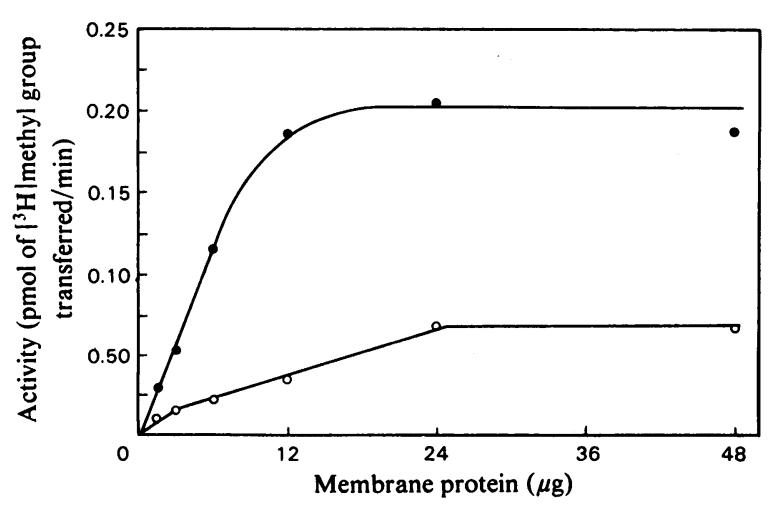

Fig. 7. Effect of membrane concentration on its methylation by the purified methyltransferase

The assay was done as described in the Materials and methods section, except that incubation was performed for $7 \mathrm{~min}$. Q, Membrane from wild-type; $\mathrm{O}$, membrane from mutant strain (OI 1100). 


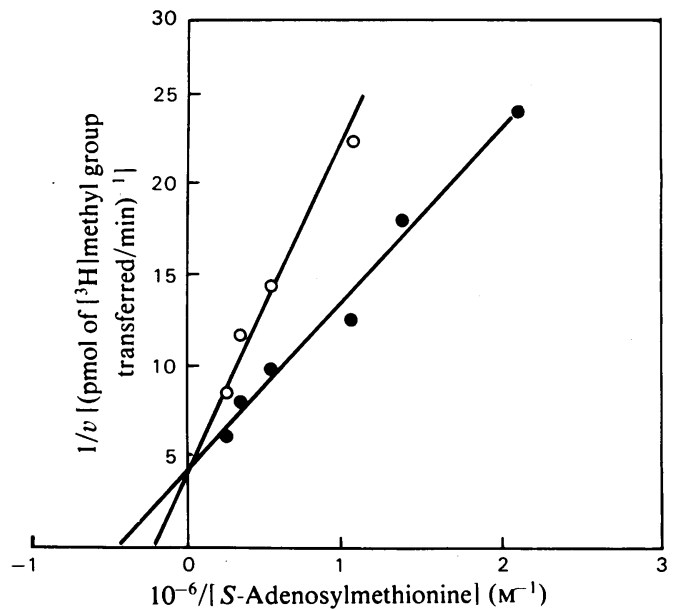

Fig. 8. Lineweaver-Burk plot of inhibition of the methyltransferase by $S$-adenosylhomocysteine

The assay was done as described in the Materials and methods section, except that incubation was performed for $7 \mathrm{~min}$. No inhibitor present; $O$, $0.1 \mu \mathrm{M}$-S -adenosylhomocysteine present.

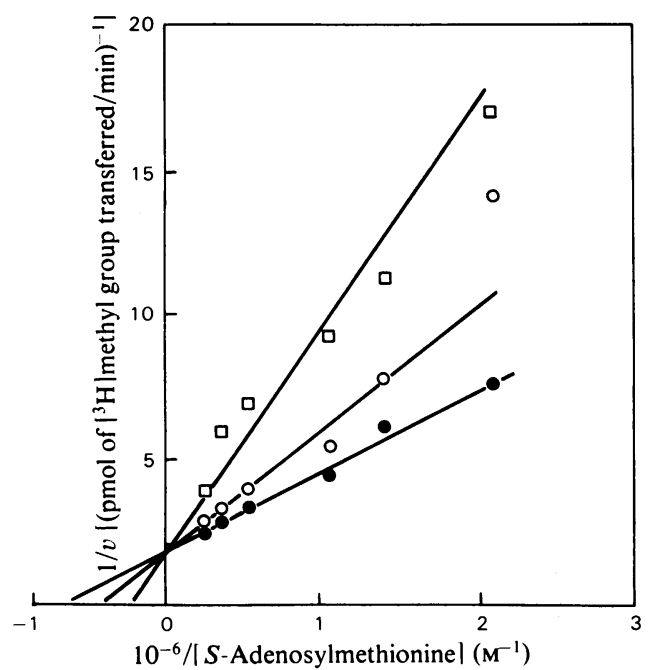

Fig. 9. Lineweaver-Burk plot of inhibition of the methyltransferase by $\mathrm{Ca}^{2+}$

The assay was done as described in the Materials and methods section, except that incubation was performed for $15 \mathrm{~min}$. $1 \mathrm{mM}$-EGTA (no inhibitor

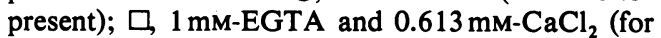
$0.1 \mu \mathrm{M}$ free $\mathrm{Ca}^{2+}$ present; $0,1 \mathrm{mM}-E G T A$ and $0.252 \mathrm{mM}-\mathrm{CaCl}_{2}$ (for $0.04 \mu \mathrm{M}$ free $\mathrm{Ca}^{2+}$ ) present.

chemotaxis (Ordal, 1977; Ordal \& Fields, 1977), $\mathrm{Ca}^{2+}$ was tested as an effector in the methyltransferase reaction. The reaction was inhibited competitively with $S$-adenosylmethionine, as deter- mined by plotting inhibition caused by $0.1 \mu \mathrm{M}$ - and $0.04 \mu \mathrm{M}$-free $\mathrm{Ca}^{2+}$ by the Lineweaver-Burk method (Fig. 9). $K_{\mathrm{i}}$ was about $0.065 \mu \mathrm{M}-\mathrm{Ca}^{2+}$.

\section{Characterization of the product formed in vitro}

In order to characterize the product of the methyltransferase reaction in vitro, membranes from wildtype and mutant strains were incubated with purified enzyme and the products were solubilized and separated by SDS/polyacrylamide-gel electrophoresis (10-18\% polyacrylamide gradient) (Fig. 10). The major methylated species in the wild-type membrane were 69000-mol.wt. and 19000-mol.wt. proteins (Fig. 10, lanes $b$ and $h$ ) and in the mutant membrane was the 19000-mol.wt. protein (Fig. 10, lanes $f$ and $j$ ). When the enzymic reaction was performed at $37^{\circ} \mathrm{C}$, methylation of the 19000 -mol.wt. protein was favoured (Fig. 10 , lane $b$ ); at $32^{\circ} \mathrm{C}$, methylation of the 69000-mol.wt. protein was favoured (Fig. 10, lane $h$ ). The 69000-mol.wt. protein is a methylaccepting chemotaxis protein (Ullah \& Ordal, 1981). The role of the 19000 -mol.wt. protein in chemotaxis remains to be elucidated.

\section{Characterization of the methylated residue}

Wild-type membrane was methylated in vitro, fractionated by SDS/polyacrylamide-gel electrophoresis, and the 69000-mol.wt. region cut out and treated as described in the Materials and methods section. Descending paper chromatography of the enzymic hydrolysate is shown in Fig. 11. All the radioactivity co-migrated with glutamate methyl ester $\left(R_{F} 0.47\right)$. By contrast, when mutant membrane was methylated in vitro (under these conditions no 69000-mol.wt. protein becomes methylated; Fig. 10) and subjected to enzymic hydrolysis, the only peak obtained was at $R_{F} 0.13$, which did not correspond to that of any of the standards used. Treatment at $\mathrm{pH} 9.8$ for $1 \mathrm{~h}$, a condition that degrades nearly all the ester to free glutamate, did not affect the amount of radioactivity at $R_{F} 0.13$. Therefore this substance does not contain a glutamate methyl ester moiety.

\section{Discussion}

We have purified a methyltransferase from $B$. subtilis to virtual homogeneity by three chromatographic steps, involving a salt gradient on a DEAE-Bio-Gel A column, chromatography on a $S$-adenosylhomocysteine-Sepharose 4B affinity column and chromatography on an Affi-Gel Blue column. We designate the enzyme methyltransferase I, since we have recently purified a second methyltransferase from $B$. subtilis (methyltransferase II), which methylates all the methyl-accepting chemotaxis proteins (see Fig. 10, lane c), of approx. 70000 mol.wt. (A. Burgess-Cassler \& G. Ordal, unpublished work). 


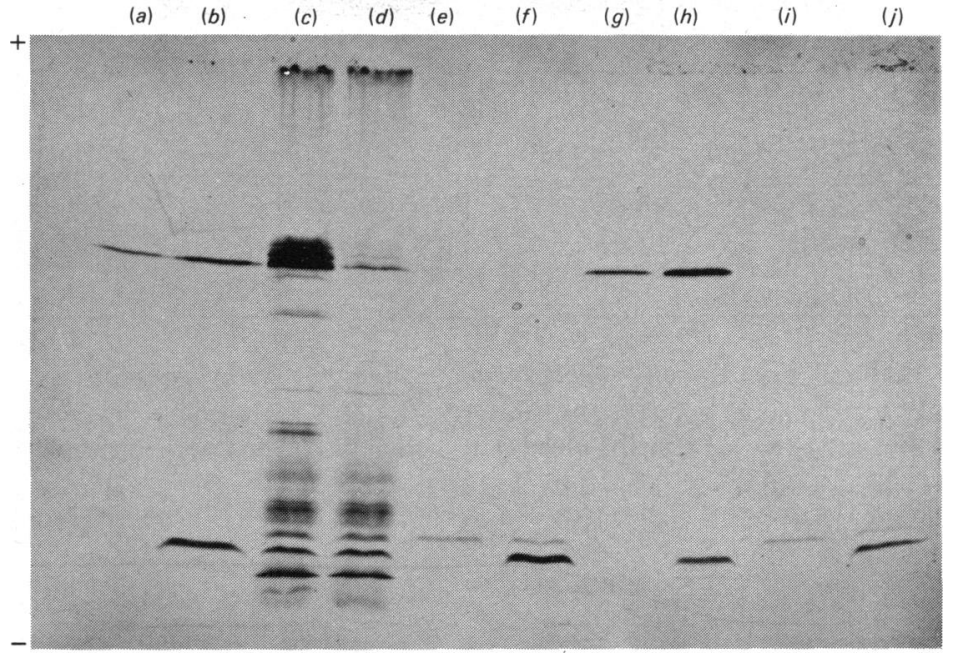

Fig. 10. SDS/polyacrylamide-gel electrophoresis of the product of the methyltransferase reaction

The assay was done as described in the Materials and methods section, except that incubation was performed for $45 \mathrm{~min}$. Temperature of incubation: $37^{\circ} \mathrm{C}$ for lanes $(a),(b),(e)$ and $(f) ; 32^{\circ} \mathrm{C}$ for lanes $(g),(h),(i)$ and $(j)$. Contents were as follows: $(a) 0.192 \mathrm{mg}$ of wild-type membrane: $(b) 0.192 \mathrm{mg}$ of wild-type membrane $+0.35 \mu \mathrm{g}$ of enzyme; (c) $0.16 \mathrm{mg}$ of wild-type proteins labelled in vivo; $(d) 0.16 \mathrm{mg}$ of mutant $(\mathrm{OI} 1100)$ proteins labelled in vivo; $(e)$ $0.192 \mathrm{mg}$ of mutant (OI 1100) membrane; $(f) 0.192 \mathrm{mg}$ of mutant (OI 1100) membrane $+0.35 \mu \mathrm{g}$ of enzyme; $(\mathrm{g})$ $0.192 \mathrm{mg}$ of wild-type membrane; $(h) 0.192 \mathrm{mg}$ of wild-type membrane $+0.35 \mu \mathrm{g}$ of enzyme; $(i) 0.192 \mathrm{mg}$ of mutant (OI 1100) membrane; $(j) 0.192 \mathrm{mg}$ of mutant (OI 1100) membrane $+0.35 \mu \mathrm{g}$ of enzyme.

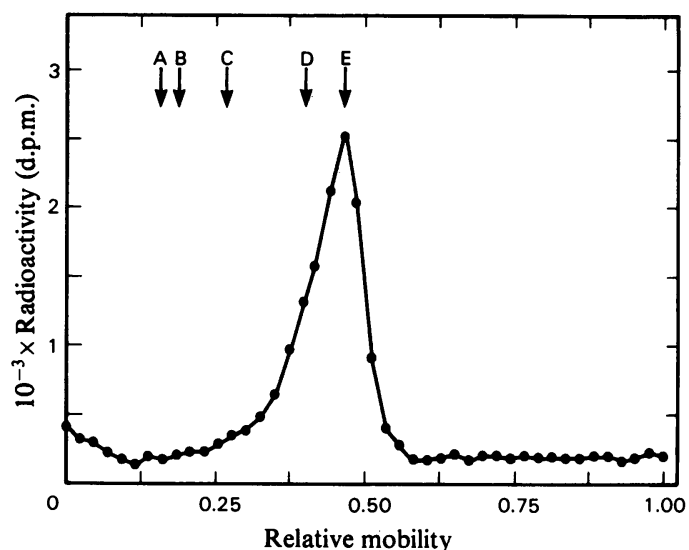

Fig. 11. Descending paper chromatography of proteolytic digest of methyltransferase-catalysed $\left[{ }^{3} \mathrm{H}_{3}\right]$ methyllabelled methyl-accepting chemotaxis protein

The 69000-mol.wt. methyl-accepting chemotaxis protein was labelled, fractionated by SDS/polyacrylamide-gel electrophoresis from other proteins, and digested by proteinases as described in the Materials and methods section. The digest was applied to the origin of a paper chromatogram $(2.5 \mathrm{~cm}$ wide $\times 48 \mathrm{~cm}$ long; Whatman $3 \mathrm{MM})$ along with $0.2 \mu \mathrm{mol}$ of the following amino acids methylated on their side chains: A, $N^{\varepsilon}$-methyl-lysine; $\mathrm{B}, N^{1}$-methylhistidine; $\mathrm{C}, N^{\mathrm{G}}$-methylarginine; $\mathrm{D}$, 4-methyl aspartate; E, 5-methyl glutamate. The chromatogram was developed in butan-1-ol/acetic acid/water (12:3:5, by vol.) for $14.5 \mathrm{~h}$.
The role of methyltransferase $I$ in chemotaxis is as yet not defined. However, several lines of evidence suggest its importance. (1) In vitro, the enzyme methylates membrane obtained from a wildtype strain much better than membranes from mutants that show no methylation of methylaccepting chemotaxis proteins in vivo (Table 2). (2) Analysis of the methylated product by SDS/polyacrylamide-gel electrophoresis reveals that the 69000-mol.wt. membrane protein is methylated in the wild-type strain, whereas the same protein cannot be methylated in a chemotactic mutant (Fig. 10). This mutant (OI 1100) is unable to methylate its methyl-accepting chemotaxis proteins in vivo despite the presence of functional methyltransferase (Ullah \& Ordal, 1981). (3) The purified enzyme cannot methylate $E$. coli membranes (Table 2). (4) The enzyme forms a glutamate methyl ester residue in methylating the 69000mol.wt. methyl-accepting chemotaxis protein. In $E$. coli, the methyl-accepting chemotaxis proteins are methylated on glutamate residues on addition of attractant (Kleene et al., 1977). Similarly, in $B$. subtilis the methyl-accepting chemotaxis proteins whose degree of methylation is affected by addition of attractant also contain glutamate residues that are susceptible to methylation (J. Ahlgren \& G. Ordal, unpublished work). (5) The enzyme is inhibited by $\mathrm{Ca}^{2+}$ at very low concentrations, which is possibly expected if $\mathrm{Ca}^{2+}$ plays some role in affecting 
Table 2. Methylation of bacterial membranes in vitro

$\begin{array}{lcc}\text { Bacterial strain } & \begin{array}{c}\text { Activity (pmol of }\left[{ }^{3} \mathrm{H}\right] \text { methyl group } \\ \text { transferred/min) }\end{array} & \begin{array}{c}\text { Extent of } \\ \text { methylation (\%) }\end{array} \\ \text { B. subtilis OI 1085 } & 0.075 & 100 \\ \text { B. subtilis OI 1100 } & 0.016 & 21.3 \\ \text { B. subtilis } \text { OI 1141 } & 0.022 & 29.3 \\ \text { E. coli AW405 } & 0 & 0\end{array}$

Table 3. Comparison of bacterial and mammalian methyltransferases

\begin{tabular}{|c|c|c|c|c|c|c|}
\hline Source & Mol.wt. & $\begin{array}{l}\text { Optimum } \\
\text { pH }\end{array}$ & $\begin{array}{c}K_{\mathrm{m}} \text { for } S \text {-adenosyl- } \\
\text { methionine }(\mu \mathrm{M})\end{array}$ & $\begin{array}{l}K_{1} \text { for } S \text {-adenosyl- } \\
\text { homocysteine }(\mu \mathrm{M})\end{array}$ & $\begin{array}{l}\text { Substrate } \\
\text { specificity }\end{array}$ & Reference \\
\hline $\begin{array}{l}\text { B. subtilis } \\
\text { S. typhimurium }\end{array}$ & $\begin{array}{l}44000 \\
38000\end{array}$ & $\begin{array}{c}7.0 \\
5.7-7.2\end{array}$ & $\begin{array}{r}2.0 \\
10.0\end{array}$ & 0.2 & $\begin{array}{l}\text { Narrow } \\
\text { Narrow }\end{array}$ & $\begin{array}{l}\text { Present paper } \\
\text { Springer \& Koshland } \\
\text { (1977) }\end{array}$ \\
\hline Human erythrocytes & 25000 & 7.0 & $1.9-2.0$ & - & Broad & $\underset{(1980)}{\operatorname{Kim}(1974) ; \mathrm{Kim} \text { et al. }}$ \\
\hline $\begin{array}{l}\text { Rat erythrocytes } \\
\text { Calf thymus }\end{array}$ & $\begin{array}{l}25000 \\
35000\end{array}$ & $\begin{array}{c}6.0-7.0 \\
6.0\end{array}$ & $\begin{array}{l}3.1 \\
1.05\end{array}$ & 1.6 & $\begin{array}{l}\text { Broad } \\
\text { Broad }\end{array}$ & $\begin{array}{l}\text { Kim (1974) } \\
\text { Kim \& Paik (1970) }\end{array}$ \\
\hline
\end{tabular}

bacterial behaviour (Ordal, 1977). $\mathrm{Ca}^{2+}$ is normally removed from bacterial cells by active transport (Rosen \& McClees, 1974). However, should conditions occur that slow its removal, such as transient diminution of the proton electrochemical gradient, the intracellular $\mathrm{Ca}^{2+}$ concentration would rise and the activity of the methyltransferase would diminish. $\mathrm{Ca}^{2+}$ is known to play a controlling role in such diverse biological processes as direction of swimming in Paramecium (Eckert, 1972), muscular contraction and relaxation (Van Winkle \& Schartz, 1976), and regulation of phosphorylase activity and glucose release in liver cells (AssimacoupoulosJeannet et al., 1977).

The methyl-accepting chemotaxis proteins, such as the 69000 -mol.wt. protein methylated by methyltransferase, are believed to change in state of methylation in response to change in attractant concentration. The function of the 19000-mol.wt. protein is obscure. If wild-type membranes are labelled in the presence of $S$-adenosyl[ $\left[\mathrm{Me}^{-}{ }^{3} \mathrm{H}_{3}\right]$ methionine and methyltransferase, and an excess of nonradioactive $S$-adenosylmethionine is then added, no label is simultaneously lost from the 69000mol.wt. protein and gained by the 19000-mol.wt. protein. Therefore it is methylated separately and is not a recipient of methyl groups from the 69000-mol.wt. protein.

The overall reaction scheme for the methyltransferase can be written as follows: where MCP represents methyl-accepting chemotaxis protein.

The purified methyltransferase has an absorption maximum at $262 \mathrm{~nm}$ (Fig. 6). This is an unusual spectral property of the methyltransferase, since such proteins usually exhibit absorption maxima near $278 \mathrm{~nm}$. The observed $A_{280} / A_{260}$ ratio (0.66) is indicative of low tryptophan and tyrosine content.

Table 3 indicates that the methyltransferase from $B$. subtilis is also unusual in its larger size than methyltransferases from other organisms, and shares with the enzyme from $S$. typhimurium the feature of high specificity of methylation. The mammalian enzymes can methylate a wide variety of proteins (Kim \& Paik, 1970). Ironically, however, the enzyme forms a carboxymethyl ester in the 69000 mol.wt. protein and a different linkage in the 19000 mol.wt. protein, although methylation of a glutamate followed by quantitative transfer cannot be ruled out.

This work was supported by Research Career Development Award GM00160 (to G. W. O.) and Research Grant GM21130, both from the Institute of General Medical Sciences, National Institutes of Health, Bethesda, MD, U.S.A.

\section{References}

Assimacoupoulos-Jeannet, F. D., Blackmore, P. F. \& Exton, J. H. (1977) J. Biol. Chem. 252, 2662-2669

$$
\begin{gathered}
\text { L-Methionine } \frac{S \text {-Adenosylmethionine synthetase }}{\mathrm{Mg}^{2+}, \mathrm{ATP}} S \text {-adenosyl-L-methionine } \\
S \text {-Adenosyl-L-methionine }+\mathrm{MCP} \stackrel{\text { Methyltransferase }}{\longrightarrow} \mathrm{MCP} \mathrm{CH}_{3}+S \text {-adenosyl-L-homocysteine }
\end{gathered}
$$


Berg, H. C. \& Brown, D. A. (1972) Nature (London) 239, 500-504

Catterall, W. A. (1976) J. Biol. Chem. 251, 5528-5536

Chua, G. K. \& Bushuk, W. (1969) Biochem. Biophys. Res. Commun. 37, 545-550

Cuatrecasas, P. (1970) J. Biol. Chem. 245, 3059-3065

Eckert, R. (1972) Science 176, 473-481

Fairbanks, G., Steck, T. \& Wallach, D. F. H. (1971) Biochemistry 10, 2606-2617

Galletti, P., Paik, W. P. \& Kim, S. (1978) Biochemistry 17, 4272-4276

Goy, M. F., Springer, M. S. \& Adler, J. (1977) Proc. Natl. Acad. Sci. U.S.A. 74, 4964-4968

Hazelbauer, G. L., Mesibov, R. E. \& Adler, J. (1969) Proc. Natl. Acad. Sci. U.S.A. 64, 1300-1307

Hill, R. L. \& Schmidt, W. R. (1962) J. Biol. Chem. 237, 389-396

Kim, S. (1974) Arch. Biochem. Biophys. 161, 652-657

Kim, S. \& Paik, W. P. (1970) J. Biol. Chem. 245, 1806-1813

Kim, S., Galletti, P. \& Paik, W. P. (1980) J. Biol. Chem. 255, 338-341

Kleene, S. J., Toews, M. L. \& Adler, J. (1977) J. Biol. Chem. 252, 3214-3218

Kort, E. N., Goy, M. F., Larsen, S. H. \& Adler, J. (1975) Proc. Natl. Acad. Sci. U.S.A. 72, 39393943

Laemmli, U. K. (1970) Nature (London) 227, 680 685

Macnab, R. M. \& Koshland, D. E., Jr. (1972) Proc. Natl. Acad. Sci. U.S.A. 69, 2509-2512
March, S. C., Parikh, I. \& Cuatrecasas, P. (1974) Anal. Biochem. 60, 149-152

Nakayama, T., Munoz, L. \& Doi, R. H. (1977) Anal. Biochem. 78, 165-170

O’Dea, R. F., Viveros, O. H., Axelrod, J., Aswanikumar, S., Schiffmann, E. \& Corcoran, B. A. (1978) Nature (London) 272, 462-464

Ordal, G. W. (1977) Nature (London) 270, 66-67

Ordal, G. W. \& Fields, R. B. (1977) J. Theor. Biol. 68 , 491-500.

Ordal, G. W. \& Goldman, D. J. (1975) Science 189, 802-805

Panasenko, S. M. \& Koshland, D. E., Jr. (1979) in Modulation of Protein Functions (Atkinson, D. E., ed.), pp. 273-284, Academic Press, New York

Rosen, B. P. \& McClees, J. (1974) Proc. Natl. Acad. Sci. U.S.A. 71, 5042-5046

Sedmak, J. J. \& Grossberg, S. E. (1977) Anal. Biochem. 79, 544-552

Silverman, M. \& Simon, M. (1977) Proc. Natl. Acad. Sci. U.S.A. 74, 3317-3321

Springer, M. S., Goy, M. F. \& Adler, J. (1977) Proc. Natl. Acad. Sci. U.S.A. 74, 3312-3316

Springer, W. R. \& Koshland, D. E., Jr. (1977) Proc. Natl. Acad. Sci. U.S.A 74, 533-537

Ullah, A. H. J. \& Ordal, G. W. (1981) J. Bacteriol. 145, 958-965

Van Der Werf, P. \& Koshland, D. E., Jr. (1977) J. Biol. Chem. 252, 2793-2795

Van Winkle, W. B. \& Schartz, A. (1976) Annu. Rev. Physiol. 38, 247-272 